\title{
MAGYAR MENTÁLHIGIÉNÉS SZÖVETSÉG
}

\section{ELŐZMÉNYEK}

Az egészség, illetve a lelki egészség elómozdítását célul kitúzó hazai kezdeményezések történetileg egybeestek a polgárosodás kibontakozásával. (Országos Egészségvédelmi Liga - 1904, Lelki Egészségvédelmi Szövetség - 1936). E folyamat a diktatúra időszakában törést szenvedett. Nem egyszerúen a lélektan oktatása és múvelése lehetetlenült el, de a mentális, illetve társadalmi problémák eltûnésébe vetett hit általában is a pártállami ideológia részévé vált. Így a különböző, mentálhigiénés szempontból is releváns szakmai, közösségi kezdeményezések a hetvenes évek elejétól mintegy búvópatak módjára jöttek létre. (Telefonszolgálatok, teaházak, csöves klubok, életvezetési tanácsadások, képzési programok.) E segítő szolgálatok tekintélyes része - mintegy elôvételezve a mentálhigiéné késôbbi paradigmaváltását - már akkor is az egészségügyön kívül, fóleg a közmúvelődés, az egyházak, illetve különbözố pedagógiai múhelyek keretében múködött. A nyolcvanas évek elején az akkori hatalom számára is nyilvánvalóvá (sốt alighanem riasztóvá) vált a különbözó lelki egészségi problémák drámai elterjedése - ennek nyomán a különböző szakmai próbálkozások számára is tágabb tér nyílott (Társadalmi Beilleszkedési Zavarok kutatás, Magyar Pszichiátriai Társaság megalakulása 1980). A Társaság Szociálpszichiátriai Szekciója 1985. évi beszámolója már a "Mentálhigiénés munkacsoport" tevékenységéról is tájékoztatást adott. A nyolcvanas évek derekától a diktatúra bomlási folyamatának újabb típusú kísérójelenségei ugyancsak elősegítették a segító szolgálatok térnyerését (drogproblémák, munkásszállói viszonyok, menekült-kérdés).

\footnotetext{
* Dr. Grezsa Ferenc

Magyar Mentálhigiénés Szövetség

1137 Budapest, Katona József u. 22.

E-mail: mamesz@mail.datanet.hu
} 
Mindezek nyomán már 1988-ban kísérlet történt Mentálhigiénés Egyesület életre hívására, ám e kísérlet akkor még elvetélt. Végül 1995. októberében 21-én egy, az „átmenet” kérdéseit taglaló zalaegerszegi konferenciát követố baráti találkozón született meg az elhatározás a Szövetség megalapítására. A jelenlévók (Buza Domonkos, Fodor Katalin, Grezsa Ferenc, Gyốri László és Magyar Zsuzsanna) ekkor fogalmazták meg azt a Programnyilatkozatot, melynek alapján pár hónap múlva (1995 januárjában, Győrben) hivatalosan is megalakult a Magyar Mentálhigiénés Szövetség.

\section{CÉLOK, KÜLDETÉS}

A Szövetség megalapítását elsósorban annak felismerése ihlette, hogy „az a világ, amely felé a magyar társadalom halad, nem kevésbé ellentmondásos, mint az, amelyet maga mögött hagy. A posztmodern társadalmak is tele vannak kihívásokkal, amelyek az elidegenedés, a terjedô drogkultúra, az erőszak, a fetisizált fogyasztás jelenségeivel párosulnak. Az ökológiai gondolkodás, a humán etológia és a természetes támogató rendszerek ismereteit integráló mentálhigiéné hozzájárulhat a jövó évezred magyar társadalmának humanizálódásához és demokratizálódásához" (Programnyilatkozat, www.mamesz.hu).

E küldetés mentén a Szövetség a különbözó helyi mentálhigiénés programok, múhelyek integrálását tekintette alapfeladatának, annak érdekében, hogy - mintegy „védőernyót" biztosítva számukra - hozzájáruljon szemléleti és szakmai sokszínúségük, autonómiájuk fönnmaradásához, kiteljesedéséhez. Ezt az integráló, „ernyőszervezeti” funkciót a gyakorlatban elsősorban a mentálhigiénés kultúra terjesztése, országos és Kárpát-medencei szakmai hálózat kiépítése, a lelki egészség fenntartását és kibontakozását támogató szakmai programok tervezése és kezdeményezése révén szerettük volna betölteni.

Programnyilatkozatunk a mentálhigiénét proszociális értékeken alapuló, életigenló magatartást támogató szemléletként, tudományos értelemben határterületi, holisztikus emberképet bemutató elméletként, valamint a humán szolgálatok összességét átfogó tevékenységi területként, intézményrendszerként határozta meg.

A mentálhigiéné eme fölfogását a kezdetektól és folyamatosan áthatja a közösség, jelesül a nemzeti közösség iránti elkötelezettség. Egyrészt értékválasztásként, másrészt pedig szakmai megközelítésként is, amennyiben a kulturálisan meghatározott lelki jelenségek, mentális problémák befolyásolása, kiküszöbölése kultúra specifikus, közösségi szintú válaszokat, megoldási módokat igényel. 


\section{TEVÉKENYSÉG}

A Magyar Mentálhigiénés Szövetségnek jelenleg 28 tagszervezete (köztük 1 marosvásárhelyi) és 230 egyéni tagja van (köztük 44 fố erdélyi magyar szakember), munkáját 13 fôs elnökség irányítja.

A Szövetség évente általában két konferenciát rendez, március 15. és október 23. táján. Ezeken egyrészt az „átmeneti kor” releváns problémáit, másrészt a különbözó mentálhigiénés színterek promóciós, prevenciós lehetőségeit igyekszünk elótérbe állítani. Például: „Létkérdések - szorongás és egzisztenciális félelem" (1995), "Értékek - jövókép - ifjúság” (1996), „A média szerepe a mentálhigiénében, a mentálhigiéné esélye a médiában” (1996), „Lelki kultúra a Délalföldön” (1997), „Megtartó lelki erők a munkásság létében” (1997), „Történelem és identitás” (1998), "Nemzeti közösség és lelki megújulás” (2001), „Az iskola, mint mentálhigiénés erőforrás” (2001), "Agresszió és társadalom” (2001), „Az ifjúság mentálhigiénés helyzete” (2002), „Lelki egészség a vidéki Magyarországon" (2003).

Vezetôségi és más tagjaink folyamatosan képviselik a Szövetséget különbözó olyan szakmai programokban, amelyek elsósorban a mentálhigiénés szemléletmód, illetve kultúra terjesztését szolgálják. E programok egyúttal a más szervezetekkel, intézményekkel való együttmúködést is szolgálják. Az Oktatási Minisztériummal, a Pedagógus Továbbképzési és Módszertani Központtal együttmúködve részt vettünk például a Mentálhigiénés Alapképzés Pedagógusoknak (2001) és a Mentálhigiénés Továbbképzó Múhely Pedagógusoknak (2002) címú 30 órás akkreditált programok kidolgozásában és elindításában. Hasonló szerepünk volt az iskolai drogkoordinátorok képzésében (2001). Indulásától kezdve (2000) szakmai támogatást nyújtunk a Necc Programiroda KHT-nak internetes ifjúsági mentálhigiénés programjukhoz.

E különböző együttmúködések a hálózatépitésre is jó lehetôséget kínálnak, hiszen a szakmai programokon részt vevő kollégáknak a Szövetséghez való kapcsolódás lehetóségét is fölajánljuk. E tekintetben különösen fontos körülmény, hogy a Szövetség több tagja tanít a Károli Református Egyetem Mentálhigiéné Szakirányú Továbbképzési szakán. A budapesti és erdélyi képzések hallgatóinak többsége így a Szövetséghez is kapcsolódik. A hallgatók múhelyszerú együttmúködését nem csupán az egyetemi képzés irányultsága, illetve az abban alkalmazott képzési technikák segítik eló, hanem például az is, hogy az egyes évfolyamok számára szervezetünk honlapján külön jelszóval elérhetó internetes felületet is biztosítunk. Hazai és határon túli tagjaink kapcsolatait azzal is építjük, hogy utóbbiak számára magyarországi tanulmányutakat szervezünk itthoni 
tagszervezeteinkhez. E tevékenységi körbe sorolható még, hogy 2003-ban az akkreditált továbbképzéseket elvégzett pedagógusok számára Országos Pedagógiai Mentálhigiénés Hálózatépítô Konferenciát szerveztünk.

\section{JÖVŐKÉP}

E lapban már évekkel ezelótt megjelent egy olyan szakmai jövókép, amely a Szövetség felfogását és elképzeléseit is tükrözte arról, hogyan volna javítható a magyarság lelki egészségi állapota*. Bár e javaslat nyilván aktualizálásra szorul, de továbbra is úgy véljük, hogy a kívánatos mentálhigiénés célok elérése elsősorban az érték- és normarendszer helyreállításától várható. Ennek érdekében mielóbb szükség lenne a mentálhigiénés helyzet átfogó felmérésére, illetve olyan programokra, amelyek a közösségi hagyományrendszer ápolására, az önszervezôdések támogatására, a mentálhigiénés alapellátás (tanácsadások) bővítésére, a közösség részletes és hiteles tájékoztatására, a képzések és továbbképzések rendszerének szélesítésére irányulnak. Jövőképünk lényege tehát egy ilyen átfogó nemzeti program megindulásának elősegítése. Erre Szövetségünk akkor lehet képes, ha további szívós hálózatépítés és igényes szakmai munka révén sikerül valóban széles alapokon nyugvó, aktív szakmai érdekképviseletté válnia. Közeli tervünk tehát - egyebek mellett - pedagógus tagozat megalakítása, székelyföldi iroda létesítése, illetve álláspontunk eddiginél aktívabb képviselete a (szakmai) közélet különbözô színterein. (Mint például állásfoglalás kibocsátásával tettük ezt 2004 novemberében, a kettő́s állampolgárságról szóló népszavazás kapcsán.)

Úgy ítéljük meg, hogy a Kárpát-medencei magyar mentálhigiénés hálózat kiépítése, illetve egy átfogó nemzeti mentálhigiénés program kezdeményezése az a kettôs kihívás, amelynek vállalása a Szövetségen kívül más mentálhigiénés szakmai szervezettôl a közeljövôben aligha várható. E méltó és bátor jövôkép tükrében különösen fájó, hogy idén a múködési források megszerzésére irányuló pályázatainkat a Nemzeti Civil Alapprogram (szerintünk megalapozatlan indokokkal) sorra elutasította. Ezért legsürgetóbb feladataink most nem szakmai, hanem pénzügyi jellegúek. E tény is része a Magyar Mentálhigiénés Szövetség hétköznapjainak.

\footnotetext{
* Grezsa Ferenc: Nemzeti mentálhigiénés stratégia és program. Mentálhigiéné és Pszichoszo-
} matika, 1999, 1-2: 24-37. 


\section{Névjegy}

Magyar Mentálhigiénés Szövetség

Minősítés: „kiemelkedően közhasznú” szervezet

Adószám: 18953879-1-41

Alapítva: 1995

Elnök: Grezsa Ferenc

Tiszteletbeli elnök: Buda Béla, Török Iván

Iroda: 1137 Budapest, Katona József utca 22. V. emelet 1/A

Telefon, fax: (1) 3493423

Honlap: www.mamesz.hu

E-mail: mamesz@mail.datanet.hu 